\title{
FUS/CREB3L1 Fusion Protein
}

National Cancer Institute

\section{Source}

National Cancer Institute. FUS/CREB3L1 Fusion Protein. NCI Thesaurus. Code C101056.

A predicted fusion protein encoded by the FUS/CREB3L1 fusion gene. This protein is comprised of approximately half the RNA-binding protein FUS fused to the DNA-binding basic domain and leucine zipper dimerization domain of the cyclic AMP-responsive element-binding protein 3-like protein 1. 